\title{
PRODUK MAKANAN TIDAK SESUAI SPESIFIKASI BERDASARKAN UNDANG-UNDANG NOMOR 8 TAHUN 1999 TENTANG PERLINDUNGAN KONSUMEN
}

\author{
Saefullah Yamin \\ Sari Arta Uli Sihaloho \\ Universitas Wiralodra \\ Email: ifoel_medit@yahoo.com, \\ sariartasihaoho@gmail.com
}

\begin{abstract}
Consumer Protection is a form of legal protection given to consumers in their efforts to meet their needs from things that can harm the consumers themselves. Therefore, talking about consumer protection means questioning guarantees or assurances about the fulfillment of consumer rights. In the legal field, this term is still relatively new, especially in Indonesia, while in developed countries consumer protection is discussed along with the development of industry and technology. In this study formulate the problem of how the legal protection of consumers for defective food products and how the responsibility of business actors for defective food products. The research method used is a normative juridical approach with data collection techniques through library research, both primary legal materials, namely reference books and regulations related to consumer protection, secondary legal materials, and tertiary legal regulations. The purpose of this study is to find out how the legal protection of consumers for defective food products and describe how the responsibility of business actors for defective food products. The theory used in this study uses the rule of law theory and the theory of legal protection. In this study, it can be concluded that consumers' rights are protected against products that are not in accordance with what they should be. In the case of sausages containing maggots, it is hoped that business actors or PT. So Good Food compensates for losses and improves quality control in producing its products.
\end{abstract}

Keywords: Consumer Protection, Defective Food Products, Tertiary legal regulations.

\section{PENDAHULUAN}

Pembangunan dan perkembangan perekonomian khususnya di bidang perindustrian dan perdagangan nasional telah menghasilkan berbagai variasi barang atau jasa yang dapat dikonsumsi. Selain itu globalisasi dan perdagangan bebas yang didukung oleh kemajuan teknologi telekomunikasi informatika telah memperluas ruang gerak arus transaksi barang dan atau jasa yang ditawarkan bervariasi baik produksi dalam negeri maupun produksi luar negeri. 


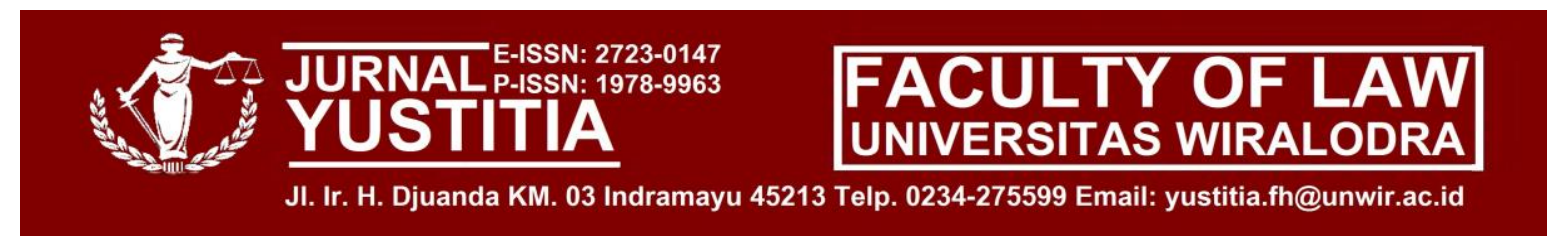

Kondisi yang demikian pada satu pihak mempunyai manfaat bagi kosnumen, karena kebutuhan konsumen akan barang dana tau jasa yang diinginkan dapat terpenuhi serta semakin terbuka lebar kebebasan untuk memilih aneka jenis dan kuantitas barang dan/atau jasa sesuai dengan keinginan dan kemampuan konsumen.

Di sisi lain, kondisi dan fenomena tersebut diatas dapat mengakibatkan kedudukan pelaku usaha dan konsumen menjadi tidak seimbang dan konsumen berada pada posisi yang lemah. Konsumen menjadi objek aktivitas bisnis untuk meraup keuntungan yang sebesarbesarnya oleh pelaku usaha melalui kiat promosi, cara penjualan serta penerapan perjanjian standar yang merugikan konsumen. Faktor utama yang menjadi kelemahan konsumen adalah tingkat kesadaran konsumen akan haknya masih rendah. Hal ini terutama disebabkan oleh rendahnya pendidikan konsumen.

Oleh karena itu Undang-Undang Nomor 8 Tahun 1999 Tentang Perlindungan Konsumen dimaksudkan menjadi landasan hukum yang kuat abgi pemerintah dan lembaga konsumen swadaya masyarakat untuk melakukan upaya pemberdayaan konsumen melalui pembinaan dan pendidikan konsumen. Upaya pemberdayaan penting karena tidak mudah mengharapkan kesadaran pelaku usaha yang pada dasarnya prinsip ekonomi pelaku usaha adalah untuk mendapatkan keuntungan semaksimal mungkin dengan modal seminimal mungkin. Prinsip ini sangat potensial merugikan konsumen, baik secara langsung maupun tidak langsung.

Disiplin hukum sebagai suatu teori tentang norma-norma tidak berhubungan dengan efektifitas norma-norma hukum. Suatu teori hukum adalah formal, suatu teori tentang caracara penertiban dan mengubah isi hukum dengan cara yang khusus. Tujuan teori hukum, seperti tiap ilmu pengetahuan adalah untukmengurangi kekacauan dan kemajemukan menjadi kesatuan. Hukum perlindungan konsumen selalu berhubungan dan berinteraksi dengan berbagai bidang dan cabang hukum lain karena ada tiap bidang dan cabang hukum itu senantiasa terdapat pihak yang berpredikat "konsumen".

Karena posisi konsumen yang lemah, ia harus dilindungi oleh hukum. Salah satu sifat sekaligus tujuan hukum itu adalah memberikan erlindungan (penganyoman) kepada masyarakat. Jadi, sebenarnya hukum konsumen dan hukum perlindungan konsumen adalah dua bidang hukum yang sulit dipidahkan dan ditarik batasnya.

Perlindungan konsumen tidak dapat dipisahkan dari kegiatan perdagangan. Dalam kegiatan perdagangan diperlukan keseimbangan antara pelaku usaha dan konsumen. Saat 
ini, di Indonesia perlindungan konsumen mendapat perhatian yang cukup baik karena menyangkut aturan dan menciptakan kesejahteraan antara pelaku usaha dengan konsumen.

Dengan adanya keseimbangan antara pelaku usaha dan konsumen maka rakyat akan makmur dan sejahtera. Dalam Pasal $28 \mathrm{~J}$ ayat (1) perubahan kedua Undang-Undang Dasar Republik Indonesia Tahun 1945 mengatur mengenai "Setia orang wajib menghormati hak asasi manusia orang lain dalam tertib kehidupan bermasyarakat, berbangsa dan bernegara". Sebagaimana diketahui dengan adanya globalisasi dan perkembangan perekonomian yang terjadi secara pesat dalam era perekonomian modern telah menghasilkan berbagai jenis dan variasi barang dana tau jasa yang dapat dikonsumsi oleh masyarakat. Produk barang dan jasa yang digunakan untuk memenuhi kebutuhan hidup manusia yang semakin lama semakin canggih, sehingga timbul kesenjangan terhadap kebenaran informasi dan daya tanggap konsumen. Dengan posisi konsumen yang lemah ini, produsen atau pelaku usaha akan dengan mudah memasarkan setiap barang dan jasa tanpa memperhatikan hak-hak konsumen.

Perlindungan konsumen mutlak dilakukan oleh negara sesuai dengan Resolusi Majelis Umum PBB. Di Indonesia, signifikansi pengaturan hak-hak konsumen melalui Undang-Undang merupakan bagian dari implementasi sebagai suatu negara kesejahteraan, karena Undang-Undang Dasar 1945 disamping sebagai konstitusi ekonomi, yaitu konstitusi yang mengandung ide negara kesejahteraan yang tumbuh berkembang karena pengaruh sosialisme sejak abad 19, melalui Undang-Undang No. 8 Tahun 1999 tentang Perlindungan Konsumen, menetapkan 9 (Sembilan) hak konsumen.

Pentingnya hak-hak konsumen, sehingga melahirkan pemikiran yang berpendapat bahwa hak-hak konsumen merupakan "generasi keempat hak asasi manusia", yang dalam perkembangan di masa-masa yang akan datang. Kehadiran Undang-Undang No.8 Tahun 1999 tentang Perlindungan Konsumen menjadi tonggak sejarah perkembangan hukum perlindungan konsumen di Indonesia. Diakui, bahwa undang-undang tersebut bukanlah yang pertama dan terakhir, karena sebelumnya telah ada beberapa rumusan yang melindungi konsumen yang tersebar dalam beberapa peraturan perundang-undangan. Undang-undang ini mengatur tentang kebijakan perlindungan konsumen, baik menyangkut hukum materiil maupun hukum formil.

Pengertian konsumen menurut Undang-Undang Perlindungan Konsumen adalah setiap pemakai barang dan/ jasa yang tersedia dalam masyarakat, baik bagi kepentingan diri sendiri, keluarga, orang lain mauun makhluk hidup lain dan tidak untuk diperdagangkan. 


\section{IDENTIFIKASI MASALAH}

Berdasarkan latar belakang masalah diatas maka penulis dapat mengidentifikasi permasalahan sebagai berikut:

1. Bagaimana perlindungan hukum terhadap konsumen dihubungkan dengan kasus produk makanan cacat?

2. Bagaimana pertanggungjawaban akan produk yang Terdapat Kecacatan?

\section{METODE}

Metode yang digunakan dalam penelitian ini adalah metode pendekatan yuridis normative, atau penelitian hukum kepustakaan, yaitu penelitian hukum yang dilakukan dengan cara meneliti bahan pustaka atau data sekunder. Dalam hal ini dengan mengkaji permasalahan dari segi hukum yang terdapat dalam Undang-Undang No 8 Tahun 1999 serta dari pustaka yang relevan dengan pokok bahasan.

\section{LANDASAN TEORITIS}

Teori merupakan pengetahuan ilmiah yang mencaku penjelasan mengenai suatu faktor dari sebuah disiplin ilmiah. Dalam dunia ilmu, teori menempati kedudukaan sangat penting, karena teori memberikan sarana untuk dapat merangkum serta memahami masalah yang dibicarakan secara lebih baik. Hal-hal yang semula tampak tersebar dan berdiri sendiri dapat disatukan dan ditunjukan kaitannya satu sama lain secara lebih bermakna. Pada suatu penelitian teori memiliki fungsi sebagai pemberi arahan kepada penelitian dalam melakukan penelitan. Untuk mengkaji suatu permasalahan hukum secara lebih mendalam diperlukan teori-teori yang berupa serangkaian asumsi, konsep, definisi dan proposisi untuk menerangkan suatu fonemena sosial secara sistematis dengan cara merumuskan hubungan antara konsep teori ini juga sangat diperlukan dalam penulisan karya ilmiah dalam tatanan hukum positif konkrit.

Indonesia adalah negara yang berdasarkan atas hukum menurut Pasal 1 ayat (3) Undang-Undang Dasar Negara Republik Indonesia Tahun 1945. Pasal ini menghendaki bahwa penyelenggaraan pemerintahan didasarkan atas prinsip-prinsip hukum untuk membatasi kekuasaan pemerintah dan ini artinya kekuasaan negara melalui aparatnya dibatasi oleh hukum (Rechtsstaat), bukan didasar atas kekuasaan (Machtsstaat). 
Suatu negara dapat dikatakan sebagai negara hukum apabila memenuhi unsur-unsur negara hukum. Friedrich Julius Stahl mengemukakan ciri-ciri suatu negara hukum sebagai berikut :

a. Adanya atas pengakuan hak-hak dasar manusia.

b. Adanya pembagian kekuasaan.

c. Pemerintahan berdasarkan peraturan.

d. Adanya Peradilan Tata Usaha Negara.

Disamping Julius Stahl, konsep negara hukum di Eropa Kontinental juga dikembangkan oleh Immanuel Kant, Paul Laband, Fichte dan lain sebagainya dengan menggunakan istilah Jerman "Rechtstaat". Dalam tradisi Anglo Saxon pengembangan konse negara hukum dipelopori oleh A.V Dicey dengan istilah "the rule of law". A.V Dicey mengemukakan unsur-unsur the rule of law sebagai berikut:

a. Supremacy of law

b. Equality before the law

c. Constitution on human right

Terdapat dalam catatan sejarah diungkapkan bahwa konsep negara hukum dapat dibedakan menurut konsep Eropa Kontinental yang biasa dikenal dengan rechstaat dan dalam konsep Anglo Saxon dikenal Rule of Law. Dengan demikian dapat dikatakan bahwa Rechstaat tersebut direduksi dalam sistem hukum yang dinamakan Civil Law atau yang biasa kita sebut dengan Modern Roman Law. Konsep Rechstaat itu telah secara historis merupakan penentangan secara tujuan atas pemikiran kaum Hegelianisme yang mengembangkan absolutism, jadi dapat dikatakan sebagai revolusioner. Berbeda denan Rule of Law yang berkembang dengan evolusioner yang direduksi dengan sistem hukum Common Law $^{1}$.

Menurut Undang-Undang Nomor 8 Tahun 1999 tentang Perlindungan Konsumen pasal 1 angka 1 yang menyatakan bahwa Perlindungan Konsumen adalah segala upaya yang menjamin adanya kepastian hukum untuk memberi perlindungan kepada konsumen. Sejalan dengan maksud dan tujuan gerakan perlindungan konsumen yang dilakukan negara-negara maju dan berkembang di dunia ini. Seperti halnya di Indonesia, kehadiran Undang-Undang

\footnotetext{
1 Philipus. M. Hadjon, Perlindungan Hukum Bagi Rakyat Indonesia: Sebuah Studi Tentang PrinsipPrinsipnya, Penerapannya oleh Pengadilan dalam Lingkungan Peradilan Umum dan Pembentukan Peradilan Administrasi Negara, Bima Ilmu, Surabaya, 1987, hlm. 90.
} 


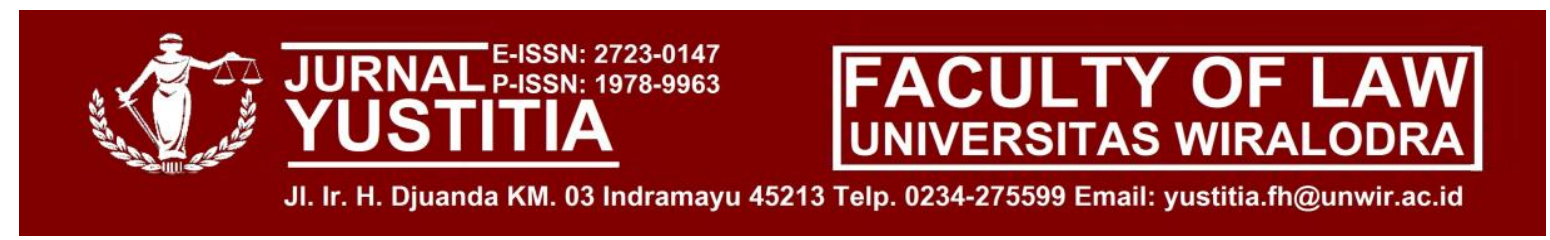

No. 8 Tahun 1999 tentang perlindungan konsumen menjadi tonggak sejarah perkembangan hukum perlindungan konsumen di Indonesia, walaupun undang-undang ini bukanlah aturan yang pertama dan terakhir karena sebelumnya ada beberapa rumusan hukum yang melindungi konsumen tersebar dalam beberapa aturan perundang-undangan yang ada. Namun, tetap saja memiliki tujuan yang tersirat. Tujuan dari Undang-Undang Perlindungan Konsumen adalah:

a. Meningkatkan kesadaran, kemampuan dan kemandirian untuk melindungi diri.

b. Mengangkat hartaka dan martabat konsumen dengan cara menghindarkannya dari akses negative pemakaian barang dan/atau jasa.

c. Meningkatkan pemberdayaan konsumen dalam memilih, menentukan dan menuntut hak-haknya sebagai konsumen.

d. Menciptakan perlindungan konsumen yang mengandung unsur kepastian

e. Menumbuhkan kesadaran pelaku usaha mengenai pentingnya perlindungan konsumen sehingga tumbuh sikap yang jujur dan bertanggung jawab dalam berusaha

f. Meningkatkan kualitaas barang dan/atau jasa yang menjamin kelangsungan usaha produksi barang dan/atau jasa, kesehatan, kenyamanan, keselamatan, dan keamanan konsumen.

Menurut Fitzgerald, dia menjelaskan teori perlindungan hukum salmond bahwa hukum bertujuan mengintegrasi dan mengkoordinasi berbagai kepentingan di masyarakat, karena dalam suatu lalu lintas kepentingan, perlindungan terhadap kepentingan tertentu hanya dapat dilakukan dengan cara membatasi berbagai kepentingan di pihak lain. Perlindungan hukum harus melihat tahapan yakni perlindungan hukum lahir dari suatu ketentuan hukum dan segala peraturan hukum yang diberikan oleh masyarakat tersebut untuk mengatur hubungan perilaku antara anggota-anggota masyarakat dan antara perseorangan dengan pemerintah yang dianggap mewakili kepentingan masyarakat.

Menurut Satjipto Raharjo, Perlindungan Hukum adalah memberikan pengayoman terhadap hak asasi manusia (HAM) yang dirugikan orang lain dan perlindungan ini diberikan kepada masyarakat agar menikmati suatu hak-hak yang diberikan oleh hukum ${ }^{2}$. Patut dicacat bahwa upaya untuk mendapatkan perlindungan hukum tentunya yang diinginkan oleh

\footnotetext{
${ }^{2}$ Satjipto Raharjo, Ilmu Hukum, Cita Aditia Bakti, Bandung, 2000, hlm. 53.
} 
manusia adalah ketertiban dan keteraturan antara lain nilai dasar dari hukum yakni adanya kepastian hukum, kegunaan hukum serta keadilan hukum meskipun pada umumnya dalam praktek ketiga nilai dasar tersebut bersitegang, namun haruslah diusahakan untuk ketiga dasar tersebut haruslah bersamaan.

\section{HASIL DAN PEMBAHASAN}

A. Bagaimana perlindungan hukum terhadap konsumen dihubungkan dengan kasus produk makanan cacat?

Penegasan dari pembuat Undang-Undang Nomor 8 Tahun 1999 tentang Perlindungan Konsumen ini sebagai mana dimuat dalam bagian penjelasan bahwa Undang-Undang Nomor 8 Tahun 1999 tentang Perlindungan Konsumen. Terbuka kemungkinan terbentuknya undang-undang baru yang pada dasarnya memuat ketentuan-ketentuan yang melindungi konsumen. Dari isinya, Undang-Undang Nomor 8 Tahun 1999 tentang Perlindungan Konsumen ini memuat garis-garis besar, sebagai berikut:

\section{Ketentuan Umum}

Pada Bab I Pasal 1 memuat pengertian-pengertian tentang beberapa kata dan istilah yang dipakai di dalam undang-undang ini, misalnya, tentang pengertian perlindungan konsumen, konsumen, pelaku usaha, barang, jasa, promosi, dan sebagainya. Ketentuan ini adalah tafsiran yuridis/resmi tentang kata atau istilah yang dimaksud tersebut.

2. Asas dan tujuan

Pada Bab II Pasal 2 memuat lima asas perlindungan konsumen, yaitu asas manfaat, keadilan, keseimbangan, keamanan dan keselamatan konsumen, serta kepastian hukum. Pada Pasal 3 dimuat tentang tujuan yang diharapkan akan tercapai melalui pemberlakuan undang-undang ini, yang pada intinya adalah meningkatkan kesadaran konsumen untuk melindungi diri, mengangkat harkat dan martabat konsumen, menciptakan sistem perlindungan konsumen yang mengandung unsur kepastian hukum, dan menumbuhkan kesadaran pelaku usaha. 
3. Hak dan Kewajiban

Pada Bab III Pasal 4 dan 5 mengatur hak dan kewajiban kosnumen, sedangkan Pasal 6 dan 7 mengatur hak dan kewajiban produsen sebagai pelaku usaha.

4. Perbuatan yang Dilarang bagi Pelaku Usaha

Pada Bab IV Pasal 8-17, yaitu sejumlah perbuatan yang terlarang untuk dilakukan oleh pengusaha dalam menjalankan usahanya, yaitu berkaitan dengan memproduksi dana atau mengedarkan produk, promosi dan periklanan, penjualan dengan cara obral dan sejenisnya, dan penjualan dengan memberikan hadiah, menjual melalui pesanan, dan dalam hal memproduksi iklan.

5. Ketentuan Pencantuman Klausula Baku

Pada Bab V Pasal 18 mengatur batasan-batasan penggunaan klausula baku dalam transaksi konsumen untuk menghindari kesewenang-wenangan pelaku usaa sekaligus melindungi konsumen.

6. Tanggung Jawab Pelaku Usaha

Pada Bab VI Pasal 19-28 mengatur tentang tanggung jawab pelaku usaha di dalam mennjalankan usahanya, baik tanggung jawab publik maupun tanggung jawab privat, baik dalam berproduksi dan mengedarkan, mengimpor, atau memasukkan barang dari luar negeri maupun mempromosikan dan mengiklankan.

7. Pembinaan dan Pengawasan

Pada Bab VII Pasal 29-30 memuat ketentuan-ketentuan tentang pelaksanaan pembinaan dan pengawasan usaha dalam rangka meningkatkan perlindungan konsumen sehingga tujuan undang-undang ini tercapai

8. Badan Perlindungan Konsumen Nasional (BPKN)

Pada Bab VIII Pasal 31-43 memuat ketentuan tentang BPKN sebagai badan khudud di bidang perlindungan konsumen yang meliputi ketentuan tentang fungsi, tugas, susunan organisasi, dan keanggotaannya sebagai sebuah badan yang bertanggung jawab dalam meningkatkan perlindungan kepada konsumen secara nasional. 
9. Lembaga Perlindungan Konsumen Swadaya Masyarakat (lpksm)

Pada Bab IX Pasal 44 memuat ketentuan-ketentuan tentang pengakuan LPKSM dalam menguayakan peningkatan perlindungan konsumen serta aturan mengenai eksistensi dan tugas lembaga konsumen swadaya masyarakat.

10. Penyelesaian Sengketa

Pada Bab X Pasal 45-48 memuat ketentuan-ketentuan tentang penyelesaian sengketa konsumen, baik di dalam maupun di luar pengadilan.

11. Badan Penyelesaian Sengketa Konsumen (BPSK)

Pada Bab XI Pasal 49-58 memuat ketentuan-ketentuan tentang eksistensi, tugas, dan wewenang Badan Penyelesaian Sengketa Konsumen.

\section{Penyidikan}

Pada Bab XII Pasal 59 memuat ketentuan-ketentuan tentang penyidikan perkara konsumen yang diduga memenuhi unsur-unsur pidana.

13. Sanksi

Pada Bab XIII Pasal 60-63 memuat ketentuan tentang jenis dan penjatuhan/pemberian sanksi, baik sanksi administrative maupun sanksi pidana kepada pelaku pelanggaran undang-undang ini.

14. Ketentuan Peralihan

Pada Bab XIV Pasal 64 memuat ketentuan tetang peralihan dari keadaan yang lalu ke keadaan pada masa berlakunya undnag-undang ini.

\section{Ketentuan Penutup}

Pada Bab XV Pasal 65 memuat ketentuan tentang mulai berlakunya undangundang ini, yaitu satu tahun setelah diundangkannya (20 April 2000) ${ }^{3}$.

Perlindungan hukum kepada konsumen dimuat dalam Pasal 4 Undang-Undang Nomor 8 Tahun 1999, signifikansi pengaturan hak-hak konsumen melalui UndangUndang merupakan bagian dari implementasi sebagai suatu negara kesejahteraan, karena Undang-Undang Dasar 1945 di samping sebagai konstitusi politik juga dapat disebut konstitusi ekonomi, yaitu konstitusi, yang mengandung ide negara kesejahteraan yang tumbuh berkembang karena pengaruh sosialisme sejak abad sembilan belas. Melalui

3 Janus Sidabalok, Hukum Perlindungan Konsumen di Indonesia, PT. Citra Aditya Bakti, Bandung, 2014, hlm. 44 


\section{TURNALE-ISSN: 2723-0147}

Undang-Undang Nomor 8 Tahun 1999 Tentang Perlindungan Konsumen menetapkan 9 (Sembilan) hak konsumen, yaitu: ${ }^{4}$

1. Hak atas kenyamanan, keamanan, dan keselamatan dalam mengkonsumsi barang dan/ atau jasa;

2. Hak untuk memilih barang dan/ atau jasa serta mendapatkan barang dan/atau jasa tersebut sesuai dengan nilai tukar dan kondisi serta jaminan yang dijanjikan;

3. Hak atas informasi yang benar, jelas, dan jujur mengenai kondisi dan jaminan barang dan/ atau jasa;

4. Hak untuk didengar pendapat dan keluhannya atas barang dan/ atau jasa yang digunakan;

5. Hak untuk mendapatkan pembinaan dan pendidikan konsumen;

6. Hak untuk mendapatkan pembinaan dan pendidikan konsumen;

7. Hak untuk diperlakukan atau dilayani secara benar dan jujur tidak diskriminatif;

8. Hak untuk mendapatkan konpensasi, ganti rugi dan/ atau penggantian, apabila barang dan/ atau jasa yang diterima tidak sesuai dengan perjanjian atau tidak sebagaimana mestinya;

9. Hak-hak yang diatur dalam ketentuan peraturan perundang-undangan lainnya.

Sembilan butir hak konsumen yang diberikan di atas, terlihat bahwa masalah kenyamanan, keamanan, dan keselamatan konsumen merupakan hal yang paling pokok dan utama dalam perlindungan konsumen. Barang dan/ atau jasa yang penggunaannya tidak memberi kenyamanan, terlebih yang tidak aman atau membahayakan keselamatan konsumen jelas tidak layak untuk diedarkan dalam masyarakat. Selanjutnya, untuk menjamin bahwa suatu barang dan/ atau jasa dalam penggunaannya akan nyaman, aman maupun tidak membahayakan konsumen penggunanya, maka konsumen diberikan hak untuk memilih barang dan/ atau jasa yang dikehendakinya berdasarkan atas keterbukaan informasi yang benar, jelas dan jujur. Jika terdapat penyimpangan yang merugikan, konsumen berhak untuk didengar, memperoleh advokasi, pembinaan, perlakuan yang adil, kompensasi sampai ganti rugi.

\footnotetext{
4 Pasal 4 Undang-Undang Nomor 8 Tahun 1999 tentang Perlindungan Konsumen.
} 
Hak-hak dalam Undang-Undang Perlindungan Konsumen di atas merupakan penjabaran dari pasal-pasal yang bercirikan negara kesejahteraan, yaitu Pasal 27 ayat (2) dan Pasal 33 Undang-Undang Dasar Negara Republik Indonesia.

\section{Bagaimana pertanggungjawaban akan produk yang Terdapat Kecacatan}

Produsen sebagai pelaku usaha mempunyai tugas dan kewajiban untuk ikut serta menciptakan dan menjaga iklim usaha yang sehat yang menunjang bagi pembangunan perekonomian nasional secara keseluruhan. Karena itu, kepada produsen-pelaku usaha di bebankan tanggungjawab atas pelaksaan tugas dan kewajiban itu, yaitu melalui penerapan norma-norma hukum, kepatutan, dan menjunjung tinggi kebiasaan yang berlaku di kalangan dunia usaha. Etika bisnis merupakan salah satu pedoman bagi setiap pembangunan perekonomian nasional secara keseluruhan. Prinsip business is business, tidak dapat diterapkan, tetapi harus dengan pemahaman atas prinsip bisnis untuk pembangunan. Jadi, sejauh mungkin, pembangunan perekonomian nasional secara keseluruhan. Karena itu, kepada produsen pelaku usaha harus bekerja keras untuk menjadikan usaha memberi kontribusi pada peningkatan pembangunan nasional secara keseluruhan. Kewajiban produsen-pelaku untuk senantiasa beritikad baik dalam melakukan kegiatan usahanya (vide Pasal 7 angka 1 Undang-Undang Nomor 8 Tahun 1999 tentang Perlindungan Konsumen) berarti pelaku usaha ikut bertanggungjawab untuk menciptakan iklim berusaha yang sehat demi menunjang pembangunan nasional. Jelas ini adalah tanggungjawab punlik yang di emban oleh produsen-pelaku usaha.

Banyak ketentuan didalam Undang-Undang Nomor 8 Tahun 1999 tentang Perlindungan Konsumen ini yang bermaksud mengarahkan produsen-elaku untuk berprilaku sedemikian rupa dalam rangka menyukseskan pembangunan ekonomi nasional, khusunya di bidang usaha.

Atas setiap pelanggaranyang dilakukan oleh produsen-pelaku usaha maka kepadanya di kenakan sanksi-sanksi hukum, baik sanksi administrative maupun sanksi pidana. Beberapa pertbuatan yang bertentangan dengan tujuan untuk meciptakan iklim usaha yang sehat dapat dikategorikan sebagai perbuatan kejahatan.

Pemberian sanksi ini penting mengingat bahwa menciptakan iklim berusaha yang sehat membutuhkan keseriusan dan ketegasan. Untuk ini sanksi merupakan salah satu alat mengembalikan keadaan pada keadaan semula manakala telah terjadi pelanggaran 
(rehabilitasi) sekaligus sebagai alat preventif bagi produsen-pelaku lainnya sehingga tidak terulang lagi perbuatan yang sama.

Bentuk pertanggungjawaban administratif yang dapat dituntut dari produsen sebagai pelaku usaha diatur di dalam Pasal 60 Undang-Undang Nomor 8 Tahun 1999 tentang perlindungan Konsumen, Yaitu pembayaran ganti kerugian paling banyak Rp200.000.000.00 terhadap pelanggaran atas ketentuan tentang:

1. Kelalaian membayar ganti rugi kepada konsumen [Pasal 19 ayat (2) dan (3)];

2. Periklanan yang tidak memenuhi syarat (Pasal 20);

3. Kelalaian dalam menyediakan suku cadang (Pasal 25);dan

4. Kelalaian memenuhi garansi/jaminan yang dijanjikan.

Sedangkan pertanggung jawaban pidana yang dibebankan kepada produsenpelaku adalah:

1. Pidana penjara paling lama 5 tahun atas pelanggaran terhadap ketentuan Pasal 8 , Pasal 9, Pasal 10, Pasal 13 ayat (2), Pasal 15, Pasal 17 ayat (1) huruf a, b, c, dan e, ayat (2) dan Pasal 18.

2. Pidana enjara paling lama 2 tahun atau denda paling banyak Rp500.000.000,00 terhadap pelanggaran atas ketentuan Pasal 11, Pasal 12, Pasal 13 ayat (1), Pasal 14, Pasal 16, dan Pasal 17 ayat (1) huruf d dan $\mathrm{f}$.

3. Terhadap sanksi pidana di atas dapat dikenakan hukuman tambahan berupa tindakan:

a. Perampasan barang tertentu;

b. Pengumuman keputusan hakim;

c. Perintah penghentian kegiatan tertentu yang menyebabkan timbulnya kerugian konsumen.

d. Pembayaran ganti rugi

e. Kewajiban menarik barang dari peredaran; atau

f. Pencabutan izin usaha.

Selain pertanggungjawaban publik juga terdapat pertanggungjawaban privat, dalam Undang-Undang Nomor 8 Tahun 1999 tentang Perlindungan Konsumen diatur mengenai pertanggungjawaban produsen, yang disebut dengan pelaku usaha, pada Bab VI dengan judul Tanggung Jawab Pelaku Usaha, Pasal 19-28. 
1. Tanggung jawab pelaku usaha pada umumnya

Pasal 19 menentukan:

a. Pelaku usaha bertanggung jawab memberikan ganti rugi atas kerusakan, pencemaran, dan/ atau kerugian konsumen akibat mengonsumsi barang dan/ atau jasa yang dihasilkan atau diperdagangkan.

b. Ganti rugi sebagaimana dimaksud pada ayat (1) dapat berua pengembalian uang atau penggantian barang dan/ atau jasa sejenis atau setara nilainya, atau perawatan kesehatan dana tau pemberian santunan yang sesuai dengan ketentuan peraturan perundang-undangan yang berlaku.

c. Pemberian ganti rugi dilaksanakan dalam tenggang waktu 7 (tujuh) hari setlah tanggal transaksi.

d. Pemberian ganti rugi sebagaimana dimaksud pada ayat (1) dan ayat (2) tidak meghapuskan kemungkinan adanya tuntutan pidana berdasarkan pembuktian lebih lanjut mengenai adanya unsur kesalahan.

e. Ketentuan sebagaimana dimaksud pada ayat (1) dan ayat (2) tidak berlaku apabila pelaku usaha dapat membuktikan bahwa kesalahan tersebut merupakan kesalahan konsumen.

Yang dimaksud dengan asal 19 Undang-Undang Perlindungan Konsumen ini adalah jika konsumen menderita kerugian berupa terjadinya kerusakan, pencemaran, atau kerugian finansial dan kesehatan karena mengonsumsi produk yang diperdagangkan, produsne sebagai pelaku usaha wajib memberi ganti kerugian baik dalam bentuk pengembalian uang, enggantian barang perawatan, maupun dengan pemberian santunan. Penggantian kerugian itu dilakukan dalam waktu paling lama 7 hari setelah tanggal transaksi.

Dengan demikian, ketentuan ini tidak memaksudkan supaya persoalan diselesaikan melalui pengadilan, tetapi merupakan kewajiban mutlak bagi produsen yang memberi penggantian kepada konsumen, kewajiban yang harus di penuhi seketika. Namun demikian, dengan memperhatikan pasal 19 ayat (5) maka dapat disimpulkan bahwa yang di maksud di sini adalah kalau kesalahan tidak pada konsumen. Jika sebaliknya kesalahan ada pada konsumen, produsen dibebaskan dari kewajiban tersebut.

2. Pembuktian unsur kesalahan

Pasal 22 menentukan: 
"Pembuktian terhadap ada tidaknya unsur kesalahan dalam kasus pidana sebagaimana di maksud dalam pasal 19 ayat (4), pasal 20, dan pasal 21 merupakan beban dan tanggung jawab pelaku usaha tana menutup kemungkinan bagi jaksa untuk melakukan mebuktian”

Pasal 22 Undang-Undang Nomor 8 Tahun 1999 tentang Perlindungan Konsumen ini mempersoalkan tentang segi pidana dari masalah pelanggaran atas pasal 19, 20, dan 21 dimana pembuktian unsur kesalahan pada perkara pidana itu dibebankan pada produsen dan/atau jaksa.

3. Jika pelaku usaha menolak bertanggung jawab

Pasal 23 menentukan:

"Pelaku usaha yang menolak dan/atau tidak memberi tanggapan dan/atau tidak memenuhi ganti rugi atas tuntutan konsumen sebagai mana dimaksud dalam pasal 19 ayat (1), ayat (2), ayat(3), dan ayat (4), dapat digugat melalui Badan Penyelesaian Sengketa Konsumen atau mengajukan ke badan peradilan di tempat kedudukan konsumen.

Pasal 23 Undang-Undang Nomor 8 Tahun 1999 tentang perlindungan konsumen ini merupakan lanjutan dari ketentuan pasal 19 yang mengatakan bahwa kalau produsenpelaku usaha menolak membayar ganti kerugian kepada konsumen, produsen-pelaku dapat di gugat ke Badan Penyelesaian Sengketa Konsumen ataupun ke pengadilan.

\section{PENUTUP}

\section{A. Simpulan}

Berdasarkan permasalahan yang telah dikemukakan penulis setelah diadakan pembahasan tentang tinjauan yuridis normatif tentang perlindungan hukum terhadap konsumen pengonsumsi sosis berbelatung di Sidoardjo dan kota lainnya dihubungkan dengan Pasal 4 Undang-Undang Nomor 8 Tahun 1999 tentang Perlindungan Konsumen, maka dapat disimpulkan sebagai berikut :

1. Konsumen dilindungi hak-hak nya dalam Pasal 4 Undang-Undang Nomor 8 Tahun 1999 tentang Perlindungan Konsumen dan apabila dirugikan dapat mengajukan ganti kerugian langsung ke pengadilan atau di luar pengadilan melalui Lembaga Perlindungan Konsumen Swadaya Masyarakat. Gugatan yang dilakukan oleh 
sekelompok konsumen, lembaga konsumen swadaya masyarakat maupun pemerintah atau instansi terkait hanya dapat diajukan ke pengadilan.

2. Perlindungan hukum bagi konsumen dapat melalui perlindungan hukum represif dimana merupakan perlindungan akhir berupa sanksi bagi PT. So Good Food berupa denda dan anti kerugian karena terjadi kecacatan produk yang di produksi.

\section{B. Saran}

1. Perlu pengawasan lebih lagi terhadap produsen-pelaku usaha dalam memproduksi dan mengedarkan produk makanannya karena produk makanan rentan akan cacat produksi dan tidak dapat dianggap sepele karena dapat mempengaruhi kenyamanan, keamanan, dan kesehatan konsumen sebelum dan/atau sesudah mengkonsumsi produk makanan tersebut.

2. Perlu implementasi yang lebih tegas dan adil untuk konsumen yang dirugikan hakhaknya sebagaimana dimuat dalam Pasal 4 Undang-Undang Nomor 8 Tahun 1999 tentang Undang-Undang Perlindungan Konsumen.

\section{DAFTAR PUSTAKA}

\section{A. Buku :}

Janus Sidabalok, Hukum Perlindungan Konsumen di Indonesia, PT. Citra Aditya Bakti, Bandung, 2014

Philipus. M. Hadjon, Perlindungan Hukum Bagi Rakyat Indonesia: Sebuah Studi Tentang Prinsip-Prinsipnya, Penerapannya oleh Pengadilan dalam Lingkungan Peradilan Umum dan Pembentukan Peradilan Administrasi Negara, Bima Ilmu, Surabaya, 1987

Satjipto Raharjo, Ilmu Hukum, Cita Aditia Bakti, Bandung, 2000.

\section{B. Peraturan Perundang-Undangan}

Pasal 4 Undang-Undang Nomor 8 Tahun 1999 tentang Perlindungan Konsumen. 